A Love as Strong as Death: Divine Erotics in "Greenleaf" and The Song of Songs

\author{
Alexandra Blake Derdall \\ Chesapeake, Virginia \\ Bachelor of Arts, University of Virginia, 2015 \\ A Thesis presented to the Graduate Faculty \\ of The University of Virginia in Candidacy for the Degree of \\ Master of Arts
}

Department of Religious Studies

May, 2017 


\title{
A Love as Great as Death: Divine Erotics in "Greenleaf" and The Song of Songs
}

\begin{abstract}
She stared at the violent black streak bounding toward her as if she had no sense of distance, as if she could not decide at once what his intention was, and the bull had buried his head in her lap, like a wild tormented lover, before her expression changed. One of his horns sank until it pierced her heart and the other curved around her side and held her in an unbreakable grip.
\end{abstract}

"Greenleaf"

You have ravished my heart, my sister, my bride; you have ravished my heart with one glance of your eyes.

Song of Songs

Flannery O'Connor's short story "Greenleaf," written in 1956 and collected in the series Everything that Rises Must Converge (1965), bears the mark of her religious imagination, an imagination that animates all of her work. In this particular story, O'Connor's vision takes shape in the depiction of God's erotic love, an especially charged site for the Christian imaginary. The Song of Songs similarly explores Divine eros. "Greenleaf" and the Song of Songs, when taken together, facilitate a deeper understanding of each text, and further illuminate the mystery of what can be termed "God's erotic love." In other words, "Greenleaf" and the Song of Songs engage in a mutually enriching relationship, one that is characterized as an ever-flowering conversation centered on the question of Divine erotics. 
My goal in this essay is to draw out some of the richness within these texts, and make explicit what I will argue for as a new understanding of God's love, made discernable through these works. Specifically, I suggest that reading "Greenleaf" and the Song of Songs together yields insight about the character of God's erotic love. However, in order to uncover such insight, it is necessary to explicitly examine their relationship. To my thinking, each text creates echoes in the other as the reader moves back and forth between them. In this way, the reader acts as a mediating presence between the two texts who can mine for insight in the space opened up by those echoes.

Before I turn to the relationship between our texts, a few things should be said about O'Connor's writing in order to obviate common misunderstandings of her work. First, her message can appear to be self-evident or glaring. While I believe that the material of her message does surface readily, it does not necessarily or immediately lend itself to a simple or easily accessible message. This situation can be compared to the roots of a tree. We can see the tree and its branches without difficulty; it gives itself over to visibility with grace and we can take pleasure in the sight. However, we often take for granted the roots underneath the tree that are in fact vast and support the tree. The tree owes itself to its roots. O'Connor's message, much like the roots of the tree, supports and gives rise to the symbols that punctuate the story and are easily detectable. This, however, is among the reasons why O'Connor's writing is so often misunderstood. The symbols meant to signify are reduced to mere abstractions: "[The meaning of the story is not] simply the aggregate of symbolic codes that must be 
deciphered in order for "meaning' to be discovered." If it seems as though she were hitting you over the head with it, it is likely that the subterranean aspects of the story have not taken hold.

The second issue I want to raise has to do with the way grace operates in O'Connor's work. A very common confusion about the force of grace is that it is violent. For O'Connor, the grace itself could not be violent, because within her religious context that would suggest blasphemy. Rather, moments of violence or suffering offer an occasion for God's grace to intervene. The difference is significant and often conflated in scholarship on O'Connor. As in all of her work, grace is pivotal to the story. In her own words, she believed that "all boils down to grace." ${ }^{2}$ This distinction about the character of grace is especially crucial to "Greenleaf" because in this story, the intervention of grace results in death. Having briefly laid out these general observations about O'Connor's work, we can now turn to the relationship between "Greenleaf" and the Song of Songs.

What does it mean to say that a short story written in the 1950 's, and a Biblical text written in $3^{\text {rd }}$ century BCE (date much less certain), participates in a to-and-fro relationship? That is, a relationship defined by back and forth dialogue that excavates new discoveries in each respective text. Before I answer this question, I want to first turn to Hans-Georg Gadamer. Gadamer's notion of play as revealing the being of the work of art-in this case, artful texts - allows

\footnotetext{
${ }^{1}$ Peter M. Candler, "The Anagogical Imagination of Flannery O'Connor," Christianity and Literature, vol. 60, no. 1 (2010): 13.

${ }^{2}$ Flannery O'Connor, A Prayer Journal (New York: Farrar, Straus, Giroux, 2013) 10.
} 
me to investigate the theoretical underpinnings of the relationship between "Greenleaf" and the Song of Songs.

This essay is divided into five parts. First, I will consider the relationship between the source texts. Second, I demonstrate that relationship textually. Next, I discuss the Song of Songs and its classification as lyric poetry and the theological implications of that literary category. In the fourth part, I take up an in-depth reading of "Greenleaf." Within this fourth section, I examine Divine erotic love, the Greenleaf family, and the bull as a Christ figure, all of which filter back into the more general category of close reading. In the fifth and final section I disclose what is gained by bringing these texts together.

\section{Play as a Model for the Relationship Between "Green- leaf" and the Song of Songs}

Before I say anything about Gadamer's construction of play, let me first point out that it is a model not without certain restraints. As a result, I will treat it as a malleable paradigm, one in which there is room to push against the boundaries of play as it appears in Truth and Method (1960/1975).

For Gadamer, play is characterized by a to-and-fro movement that is not dominated by a goal, which is to say, play does not arise solely for the purpose of achieving something. This does not mean that play accomplishes nothing, only that its existence does not depend on a predetermined goal or aim. It is this lack of an ultimate telos that allows playing to renew itself in its repetitive back 
and forth motion (Truth and Method, 104). ${ }^{3}$ The absence of an explicit aim creates the conditions for potential newness in repetition, or a fresh reiteration. That is, within the confines of the boundaries set by repetition, innovation exists in the spaces opened up by the repetitive act itself. Take for example a musician who covers a song by another artist. By definition, she does indeed repeat the same song, but introduces a new style of singing, a different tempo, or uses a piano instead of a guitar for the melody. The song is a repetition, but not a mere replica. In other words, the song becomes renewed in the repetition, which contains possibilities for newness.

The regenerative power of playing engages the players, and they become absorbed into the game: in effect, the game plays the players, and not the other way around (Truth and Method, 106). To return to our previous example, the two musicians are the players, absorbed by the song - the work of art - that allows for both sameness and newness in the repetition.

This game is played out in its presentation, and all presentation can be representation for somebody. That potential for representation is embedded in art's play-act. Playing occurs by presenting itself, and presentation becomes representation when it takes place before a spectator. Keeping our musicians in mind, playing comes full circle when we hear the song in its presentation. And if all playing is presentation, as Gadamer asserts, then all play contains within it the possibility of representation (ibid., 108). Representation here means 'to refer

\footnotetext{
${ }^{3}$ Hans-Georg Gadamer, Truth and Method (New York: Continuum, 2004) 104.
} 
to,' or 'to depict.' Indeed, as Gadamer says, "That this possibility [of representation] is intended [in play] is the characteristic feature of art as play...their being [as types of play] is not exhausted by the fact that they present themselves, for at the same time they point to the audience which participates by watching" (ibid., 108). In our example, the audience participates by listening, and more generally, receiving.

If we return to the relationship between "Greenleaf" and the Song of Songs, we will see how it maps onto Gadamer's theory thus far. I started by asserting that "Greenleaf" and the Song have echoes in one another, and that the reader can navigate these reverberations by moving back and forth between the texts, as in Gadamer's theory of play. We can further describe the behavior each text exhibits in the course of their relationship as bouncing off one another-or to again borrow from Gadamer, “...the cat at play chooses the ball of wool because it responds to play, and ball games will be with us forever because the ball is freely mobile in every direction, appearing to do surprising things of its own accord" (ibid., 106). If we apply this image to our current project, both of our texts trade off the role of the cat and the role of the ball. At times and where most revelatory, "Greenleaf" may act as the cat, pushing, chasing, unraveling the ball of wool - the Song of Songs - which responds spontaneously and surprisingly. Similarly, the Song of Songs appears to mirror this play with "Greenleaf," in respect to things such as theme, subject matter, or plot. ${ }^{4}$ We can benefit

\footnotetext{
${ }^{4}$ The Song of Songs, written long before "Greenleaf," can only return this play when the reader frames it within the story.
} 
from this image of the cat at play because it portrays both the unpredictable and respondent nature of these texts in relation to one another.

To state my position before we return to Gadamer, I take "Greenleaf" and the Song of Songs to be the players, the reader a spectator, and the playing the back and forth dialogue between each text. However, for Gadamer, playing is anchored in the work of art. "Greenleaf," as a work of art, comes to reveal its being through playing, which we know manifests in presentation and ultimately, representation. The same holds true for the Song of Songs. In this situation, play grows out of the work, which in our case is "Greenleaf" and the Song of Songs, respectively and separately. I deviate from Gadamer here in that I locate playing in the interaction between the texts, rather than the texts themselves housing the site of play.

Let me also say that without counting the reader as both a spectator and a player, then part of my methodology is lost. I do intend the reader to be both witnessing play between "Greenleaf" and the Song, in addition to becoming a player herself, propelling the game by taking up and exploring the relationship between our texts. This indicates two types of play throughout this project. The first figures "Greenleaf" and the Song as two distinct players. The relationship between these texts, created by repetition, creates echoes in one another that the reader notices as a spectator. In the second type of playing, the reader advances from a spectator to a player. The reader as a player questions this relationship between "Greenleaf" and the Song of Songs. This two player ("Greenleaf" and the Song) and three player (both texts and the reader) model indicates two dif- 
ferent ways of engaging the texts. "Greenleaf" and the Song as players demonstrate the relationship between the story and the Song: each text plays metaphorically with each other. When the reader comes onto the scene as a third player, she occupies a position that allows her to inhabit an interpretive space that searches for the significance of the relationship between texts. "Greenleaf" and the Song demonstrate their relationship when the reader is a spectator, but new possibilities specific to the tri-part model arise when the reader becomes a player, interpreting the implications of that relationship. This doubling of whom we take to be players becomes a moment of necessary flexibility that I believe is revelatory when adopted.

We can take the role of the spectator/audience a step further, as Gadamer does: "But however much...play represents a world wholly closed within itself, it is as if open toward the spectator, in whom it achieves its whole significance" (ibid., 109). With the help of Gadamer, we recognize that the spectator is an essential feature of play, or more precisely, is not a feature at all, but woven into the fabric of play as such. Following Gadamer's idea to its logical end, we find that the audience is able to make the imaginative leap from merely watching to actively participating and inhabiting the world in which playing occurs. The difference between merely watching and actively participating can be compared to taking lecture notes to pass a history exam, versus going to the field where the battle took place.

This imaginative leap is an important move, because the spectator is given license to both take on the role she sees presented and fully dwell within the 
world of the work of art. This world, forged by a structured work of art, gives Gadamer the ground for what he calls transformation into structure. Gadamer describes transformation into structure as,

...[a] change, in which human play comes to its true consummation in being art, transformation into structure. Only through this change does play achieve ideality, so that it can be intended and understood as play. Only now does it emerge as detached from the representing activity of the players and consist in the pure appearance of what they are playing. As such, the play... is in principle relatable and hence permanent. It has the character of a work...In this sense I call it a structure. (ibid., 110, emphasis original)

Play that produces a work of art extends beyond itself, and allows the spectator to participate in an imminent reality. As Gadamer says, we become able to recognize that this is the way things really are: truth is made discernable by the work (ibid., 112). ${ }^{5}$ If we explore the defining attributes of transformation into structure, we find that the structured work of art is both "relatable" and "permanent." Together, the work's relatability and permanence indicate that it is open to change within the established structure. As I pointed out above, innovation exists within the spaces created by repetition.

In the light of Gadamer's articulation of the being of the work of art, I suggest that "Greenleaf" is such a work that reiterates the Song. That is, "Greenleaf" exists within an established structure, while also taking advantage of repetition in order to innovate. (In fact, O'Connor innovates to the point of stressing her received structure. This why the Song can be difficult to recognize within "Greenleaf," and the reason why our explicit inquiry of their relationship is

\footnotetext{
${ }^{5} \mathrm{Or}$, at least, this recognition becomes a possibility.
} 
called for.) Further, the Song is relatable: it continues to find expression in literary and biblical scholarship today, a fact that testifies to its permanence and contributes to the Song's endurance in new forms, "Greenleaf" being one example.

To take the point further, Gadamer claims that transformation into structure taken seriously actually results in total alteration. Something entirely new emerges and designates the work of art's "true being" (ibid., 111). "Greenleaf" works in just this way: it reveals part of the Song's true being. However, for that revelation to become possible, some adaptation of Gadamer necessarily follows. Because I take "Greenleaf" and the Song to be playing with one other, I require a variation of transformation into structure. Instead of total departure with what came before transformation, I want to hold onto the echo of what laid the foundation for transformation into structure to transpire. Therefore, Gadamer's claim, "what existed previously exists no longer" (ibid., 111), strikes me as actually losing a crucial element necessarily belonging to the work of art.

So far we have proposed that "Greenleaf" reiterates the Song within the confines laid out by repetition. This reiteration becomes both the grounds for their back and forth playing, and responsible for the innovation within repetition described above. In this situation, I need the Song to stay present, because not only is it a crucial conversation partner, it also informs how we think about and interpret the short story. If we were to stay strictly within the realm of Gadamer's construction, both texts would designate a structured work of art (which I certainly do agree with) that each underwent transformation into structure in 
their own right. In my configuration this principle persists but with flexibility that allows us to also think about the texts as players that continue to 'play out' their relationship through the mediating presence of the reader.

Gadamer goes on to say that through this transformation, the players recede into the background, and what emerges in the foreground as meaningful is the structured play, or the work of art, "What no longer exists is the playerswith the poet or composer being considered as one of the players" (ibid., 111). While I do not disagree with Gadamer on this point, in our case, I want to again introduce some flexibility into Gadamer's schema. Because I suggest that “Greenleaf" and the Song of Songs should be understood as players-in addition to works of art-I do not want them to recede, leaving the manuscripts as the only important artifacts. Instead, the texts are both the players and the work of art. Their structured play is manifest in the texts as we have them. But through the mediation of the reader, the texts begin to play off one another. Therefore, they are not simply works, but also players. In other words, they perform a double role in light of Gadamer's model: they each stand as a work of art that underwent transformation, but remain in conversation with one another through the reader's mediating presence. They bring to the surface new understanding and unnoticed insights: their conversation continues to bloom. ${ }^{6}$

If we return for a moment to Gadamer's earlier assertion that all play is presentation, we can see how he makes the move from discussing transfor-

\footnotetext{
${ }^{6}$ I acknowledge that this may appear as forcing Gadamer's theory of play to fall in line with my agenda. However, I operate under the assumption that there is room for plasticity within the construction of play as Gadamer presents it.
} 
mation into structure to recognition. Gadamer begins this transition by bringing imitation into the discussion, which he reminds us, is the classical theory of art (ibid., 113). And, as Gadamer rightly says:

...the concept of imitation can be used to describe the play of art only if one keeps in mind the cognitive import in imitation. The thing presented is there. That is the situation basic to imitation. When a person imitates something...they intend a representation of such a kind that only what is represented exists. (ibid., 113)

Presentation, representation, and imitation are all immersed in recognition. Each of these functions to spark and then stimulate the spectator's recognition of what the work of art 'means.' Imitation creates the conditions for recognition to take place, by virtue of being a repetition.

Recognition importantly relates back to representation, and is the concept with which Gadamer is most concerned. Recognition takes this position, Gadamer argues, because when we are confronted with the work of art, we are concerned about whether or not the work speaks truthfully: “...what we experience in a work of art and what invites our attention is how true it is-i.e. to what extent one knows and recognizes something and oneself" (ibid., 113). However, fully drawing out the implications of recognition as it relates to representation requires a closer examination of recognition. On this point, I quote Gadamer in full, because within it lies the animating force of my argument:

But we do not understand what recognition is in its profoundest nature if we only regard it as knowing something again that we knew already-i.e., what is familiar is recognized again. The joy of recognition is rather the joy of knowing more than is already familiar. In recognition what we know emerges, as if illuminated, from all the contingent and variable circumstances that condition it; it is grasped in its essence. (ibid., 113, emphasis original) 
The exhilaration I experienced when I first read "Greenleaf” and noticed it had a connection to the Song of Songs was not mere familiarity; it was more than a conglomeration of similar, broad strokes in theme. Instead, it was the joy of deeper knowledge and understanding when I framed these texts within each other. A practice prompted by recognition, yes, but taken further, as Gadamer says, the more. "Greenleaf," as it represents the Song of Songs, discernable to me by way of recognition, excited me because I learned new and surprising things about this ancient text when I saw it within Mrs. May's world. "Greenleaf” now to me appears as incomplete without the Song of Songs to inform and contextualize it. So, as Gadamer aptly writes, recognition and representation are not just the status quo, but a "yes, and more," an elevation of the original work. And to make the point more radical, Gadamer goes on to say that what is known in recognition actually comes "into its true being" by the occurrence of that recognition (ibid., 114). Operating in the other direction, but perhaps less obvious, I am able to reckon with the truth presented in the Song of Songs by way of "Greenleaf," which becomes a corrective lens that brings the story into focus, and vice versa.

The principle of recognition as it functions in Gadamer captures the impetus of my study. It is not only that I saw one thing in terms of another but also that there was more to learn when "Greenleaf" and the Song were held together. On recognition and imitation Gadamer makes explicit one final and significant point for us: “...one can say even more: the presentation of the essence, far from being a mere imitation, is necessarily revelatory. In imitating, one has to leave 
out and to heighten. Because he is pointing to something, he has to exaggerate, whether he likes it or not" (ibid., 114). We will see this heightening and exaggeration take concrete form in "Greenleaf." On this point, one important remark remains: if "Greenleaf" is uneven in its reiteration of the Song, it results from the very fact of genuine reiteration, which denotes the newness made possible through repetition.

In this first section, I have tried to adopt Gadamer's theory of play both as a model for the relationship between "Greenleaf" and the Song as it actually exists, and as a method I will use to examine what is revealed when these texts are held together. The doubling of play means that some flexibility must be implemented in Gadamer's theory, because there are a few moving parts within this binary system. Specifically, whom we take to be players doubles. In the first situation, "Greenleaf" and the Song designate the players, who participate in a back and forth dialoging. In the second, both texts remain players, but the spectator comes into the situation as a third player. The to-and-fro character of the relationship unearths new understanding, and in order to excavate those insights, the spectator must become a player. As we can see, the model and the method are closely intertwined, so let me say that so far we have only dealt with the model, and laid the groundwork for the method. Gadamer's theory of play sheds light on the relationship between the texts, and contributes important concepts that I will use in the argument (for example, recognition). 
We now turn to the relationship between "Greenleaf" and the Song of

Songs. In this section I play the part of spectator, moving between the echoes that resound in the texts.

\title{
III. The Intimation of the Song of Songs in "Greenleaf"
}

\begin{abstract}
I will begin where the story does. ${ }^{7}$
Mrs. May's bedroom window was low and faced on the east and the bull, silvered in the moonlight, stood under it, his head raised as if he listened-like some patient god come down to woo her-for a stir inside the room...clouds crossing the moon blackened him and in the dark he began to tear at the hedge. Presently they passed and he appeared again in the same spot, chewing steadily, with a hedge-wreath that he had ripped loose for himself caught in the tips of his horns. When the moon drifted into retirement again, there was nothing to mark his place but the sound of steady chewing. Then abruptly a pink glow filled the window. Bars of light slid across him as the venetian blind was slit. He took a step backward as if to show the wreath across his horns. ${ }^{8}$
\end{abstract}

Before unpacking this passage, I want to bring into the fold three moments from the Song of Songs that I believe "Greenleaf" plays with in this early section. The first is "My beloved is like a gazelle / or a young stag. / Look, there he stands / behind our wall, / gazing in at the windows, / looking through the lattices" (2.9). The second instance comes from the third chapter, first verse: "Upon my bed at night / I sought him whom my soul loves; / I sought him, but found him not."

\footnotetext{
${ }^{7}$ In my concentration of the resonance of the Song of Songs in "Greenleaf," and the question of Divine eros animating both, I leave to the side other interesting and relevant aspects to the story. For example, Louise Westling explores possible evocations of classical mythology. See: Louise Westling, Sacred Groves and Ravaged Gardens: The Fiction of Eudora Welty, Carson McCullers, and Flannery O'Connor (Athens: University of Georgia Press, 1985) 162-166.

${ }^{8}$ Flannery O'Connor, Collected Works (New York: The Library of America, 1988) 501.
} 
Lastly, "I slept, but my heart was awake. / Listen! my beloved is knocking. / "Open to me, my sister, my love, / my dove, my perfect one; / for my head is wet with dew, / my locks with the drops of the night" (5.2). ${ }^{9}$ The opening excerpt from "Greenleaf" blends a number of consonant themes that we encounter in these verses from the Song. Above all, I want to emphasize perspective and setting, because they contain the greatest overlap with the Song of Songs.

It is necessary to proceed with some care at this point, in order to avoid on the hand, eisegesis, and on the other, to remain deaf to the subtle resonances within the text. With that caution in mind, I want to first make a brief clarification about perspective. "Greenleaf" begins by describing the bull, and then shifts focus to Mrs. May who describes the same scene from her own perspective. While "Greenleaf" does not descend into anthropomorphism, it does manage to inhabit the orientation toward the world that the bull occupies. The bull never narrates the story in the way that Mrs. May does. However, our perspective still aligns with his by habituating his orientation. As such, what I mean when I say the "bull's perspective" is more accurately shorthand for his window on the world. As one scholar remarks,

The characters she draws...appear as terse and frequently peculiar. What seems superficially unremarkable, then, is always potentially for O'Connor eschatologically crucial, and urgent. The seduction of the secular and sensual world contains, but also requires, perceptual trans-

\footnotetext{
${ }^{9}$ This translation comes from the NRSV. I switch to the New Catholic Edition of the Holy Bible (a revision of the Douay-Rheims Bible, initially published in 1582) in the interpretive "Greenleaf" sections. According to Keith Perry, this is the "edition O'Connor herself owned, and therefore would have consulted." Keith Perry, "Straining the Soup Necessarily Thinner: Flannery O'Connor's 'Greenleaf' and Proverbs 11:28," English Language Notes, 42/2 (2004): 57.
} 
positions. Objects and events demand metamorphosis, recognizing higher apprehensions of reality. ("Encyclopedia of American Literature," 838$)^{10}$

The three moments in the Song of Songs at play with "Greenleaf" in this opening moment set the stage for this "perceptual transposition" to occur through alternating perspectives. "Greenleaf" echoes the Song by moving through oscillating focal points of the bull and Mrs. May. On this issue, while the scene centers on the bull, his description as a "god come down to woo her" alters when Mrs. May describes the scene. She calls him an "uncouth country suitor" ("Greenleaf," 502). However, they both categorize the relationship as a romantic one. This back and forth perspective becomes a site of play that reverberates in the Song: it both highlights the nature of the relationship between Mrs. May and the bull, and allows each lover to describe the relationship from their own perspective.

This early portrayal of the bull as a suitor bolsters a growing connection between the "Greenleaf" lovers and the lovers of the Song, especially because Mrs. May repeats and thus emphasizes the characterization of the bull become lover when she describes him as a suitor. To narrow our scope to a specific example, consider the wașfs of the Song. An Arabic term for description, the was fs are a poetic device in which the beloved's physical beauty is sequentially ex-

\footnotetext{
${ }^{10}$ A.F. Kinney, "Flannery O'Connor," Continuum Encyclopedia of American Literature, ed. S. Serafin, and A. Bendixen (New York: Continuum, 2005) 838.
} 
tolled, i.e., from head to toe. ${ }^{11}$ They are spoken from the perspective of the lover in reference to the beloved and allow the reader to see the beloved through the lover's eyes.

"Greenleaf," though not technically employing the genre of wasfs, renders the same function, albeit comically. Take for example a description of the bull, evocative of an abbreviated wasfs: “...from her window she saw the bull, squirrel-colored, with jutting hips and long light horns, ambling down the dirt road that ran in front of the house...'He likes to bust loose,' Mr. Greenleaf said, looking with approval at the bull's rump" ("Greenleaf," 513). While Mrs. May does take stock of the bull's body, it is a caricature more than a loving enumeration. In the story, the bull becomes an "uncouth country suitor," rather than "radiant and ruddy, outstanding among ten thousand" (Song of Songs, 5.10).

Apart from portrayals of the lovers, I want to make one final point about the function of perspective in this opening moment before we turn to concerns of setting. As I said above, the opening perspective is mediated through the bull's 'point of view,' an act that forces the reader to identify with him. If we retain the benefit of inhabiting the world of play, then it follows that the reader falls into identifying with the bull—that is, as long as O'Connor's story is successfully artful. If our instinct favors identification with the Mays or the Greenleafs, O'Connor's story interrupts this anthropomorphic tendency. To be sure,

\footnotetext{
${ }^{11}$ Richard N. Soulen, "The Wașfs of the Song of Songs and Hermeneutics," A Feminist Companion to the Song of Songs, ed. Athalya Brenner (Sheffield: Sheffield Academic Press, 1993) 183-190.
} 
Mrs. May and the bull both die in the story. Taking on the bull's perspective opens up room for a reader to question whether the story's finale constitutes a violent murder, or a charitable and loving act.

Moving from perspective to setting, where we find the second major echo of the Song, "Greenleaf" similarly begins with a bedroom scene in the night. And in both texts, a "suitor" has arrived for the purpose of courting his beloved. Echoes of the Song, embedded within "Greenleaf" begin to arise through a series of similar motifs. But, again, "Greenleaf" plays with their presentation. To be specific, the opening paragraph of "Greenleaf" blends themes from Song 2.9 and 5.2, most notably, the window and sleep. Both of these motifs filter back into the larger category of setting, and because they occur within the course of a narrative, it will be helpful to untangle and treat both separately. But in order to hear the resonances of these themes from the Song in "Greenleaf," a brief note about the character of the respective male lovers.

The type of male lover in each text must be expounded. While it seems obvious and a matter of fact, it bears making explicit. The Song contains human lovers and makes use of animal attributes to describe qualities or behaviors of the human lovers. For example, "I compare you, my love, to a mare among Pharaoh's chariots" (1.9). "Greenleaf," on the other hand, figures an animal lover that enacts human qualities in his loving. ${ }^{12}$

\footnotetext{
${ }^{12}$ As Jay Watson, remarks, "Her death has an unmistakable sexual edge to it." Jay Watson, "Flannery O'Connor," The Cambridge History of American Literature: Volume Seven: Prose Writing, 1940-1990, ed. Sacvan Berkovitch (Cambridge: Cambridge University Press, 1999) 349.
} 
The most apparent similarity between the story and the Song is the window. Without doubt, both texts exhibit the male lover's approach to the window, and their behavior at the window strengthens this parallel. ${ }^{13}$ In the Song of Songs, he gazes, and then calls out to his lover: “...there he stands / behind our wall, / gazing in at the windows, / looking through the lattice. / My beloved speaks and says to me: / 'Arise, my fair one, and come away...' (2.9-10). In "Greenleaf," the bull lingers, and then he begins to chew the hedge outside of Mrs. May's window: "his head [was] raised as if he listened...there was nothing to mark his place but the sound steady chewing" (“Greenleaf," 501). The lover's looking and bull's listening mirrors one another in their attentiveness to his beloved; likewise, this attention is mirrored in the call (Song of Songs) and the chewing (“Greenleaf"). ${ }^{14}$ If we think back to the type of lover designated in each text—one human and one animal—it follows that their behavior at the window must be accommodated to reflect that fact. The bull's method of calling out to his lover manifests in the form of noise made by chewing. ${ }^{15}$

\footnotetext{
${ }^{13}$ The main problem at this point is that perhaps the bull's status as lover is not established. While this issue is offset partially by the bull being described as "a patient god come down to woo [Mrs. May]," I suspend this concern in anticipation of coming discussion.

${ }^{14}$ I am suggesting that we read the bull's chewing as a way of him bringing attention to himself, or what amounts to the call - calling her attention to him - and becomes a comedic manifestation of "Greenleaf" playing with themes found in the Song.

${ }^{15}$ In connection with theme of the window is the lattice in the Song and the light in "Greenleaf," ("Bars of light slid across [the bull] as the venetian blind was slit,"). The behavior of light remains important throughout the story and its origins can be located in this passage. Even if the word "lattice" itself does not appear in the story, nevertheless, the bars of light cast on the bull's body by the venetian blinds-blinds that are made from "light laths fixed on strips of webbing" (OED) — strike me as akin to
} 
Having laid some groundwork of the formal considerations of setting, we can move to the appearance of sleep in each text. The female lovers sleep, or more precisely, they each undergo a sort of fever dream before they are awoken by their lover's call, a dream in which "I slept but my heart was awake" (5.2). ${ }^{16}$ In the Song, there are two scenes where the woman goes out into the city searching for her beloved (3.1-4, 5.2-8). Mrs. May similarly has two dreams. Both times, the sound of the bull chewing outside her window awakens her. On the first occasion, when "the munching reached her elbow" she rises and quickly finds the "bull, gaunt and long-legged...standing about four feet from her" ("Greenleaf," 502). In the second instance, she initially has difficulty locating him because he is "paused, as if observing her" ("Greenleaf," 519), i.e., he is disguised in the stillness of the dark ("Greenleaf," 519). ${ }^{17}$ When the bull awakes Mrs. May for the second time, she responds to his call by intently watching him until he "move[s] away in the darkness" (ibid., 519). This particular moment, in which Mrs. May and the bull observe one another, finds resonance in the Song, where the male lover exclaims: "Turn your eyes away from me, / for they over-

the pattern such as a lattice would make. If this detail is overly subtle, all the same, it helps facilitate the conversation between texts.

${ }^{16}$ In the case of "Greenleaf," Mrs. May "...had been conscious in her sleep of a steady rhythmic chewing" (502).

${ }^{17}$ The contrasted ease and difficulty Mrs. May has finding the bull in these two dream scenes further plays with the Song of Songs. In the woman of the Song's first dream scene, she finds her lover quickly. In the second, the task becomes challenging, much like Mrs. May's experiences. 
whelm me!" (6.5). Like the male lover of the Song experiencing distress at the woman's gaze, the bull, too, withdraws in response to Mrs. May's stare. ${ }^{18}$

In summary, we have noticed a number of corresponding events in "Greenleaf" and the Song of Songs. The opening paragraph of "Greenleaf" does not only echo the Song, it also plays with and alters the way various themes manifest in the story. Specifically, the theme of the window and the dream sequences take on new valence when placed in proximity to the Song. "Greenleaf," to be sure, does not merely imitate, but "heightens" by playfully making selections about characterization, exaggeration, presentation, and plot. This act results a in to-and-fro relationship with the Song that ultimately culminates in a new iteration of the Biblical text in the form of "Greenleaf." In turn, the reader as a spectator can locate and explore these reverberations between texts.

In this section, I have tried to carefully make explicit, in a limited number of instances, how these texts play with one another. How, in other words, "Greenleaf" answers to an image embedded in the Song, no matter how minor. Further, I have relied on oscillating back and forth between the short story and the Biblical text to draw out these echoes. Moving forward, I will continue demonstrating that these texts do engage in relationship, but through an in depth reading of "Greenleaf." That is, I shift gears from evidencing to interpreting the story. Echoes of the Song will naturally surface, and when they do, I name them.

\footnotetext{
${ }^{18}$ A number of scholars discuss this moment in the Song: Cheryl Exum, Michael V. Fox, and Athayla Brenner, to name just a few. For my purposes, it is enough to note that the male lover becoming an object of the gaze (a role women typically fulfill) makes him uneasy, and they both act to end it.
} 
However, the goal of the next section is to interpret "Greenleaf," rather than to primarily verify the relationship's existence.

I acknowledge that this opening paragraph may not provide a large enough sample from the story to demonstrate that a connection exists between the source texts. To that, however, I answer that the moments echoing the Song most sharply occur in the beginning and at the end. ${ }^{19}$ Because I want to bracket discussion of the story's end until interpretive work of the story has been done, I have focused primarily on the opening scenes of the story. Further, at the risk of repeating myself, "Greenleaf" is not a reproduction of the Song. The story in its own right is a structured work of art that explores the erotic dimension of God's love. As a result, it does not, nor does it aim to mirror the Song at every turn.

Before I undertake a close reading, a brief genre analysis will effectively lend itself to an interpretation of Divine eros.

\section{Linafelt on Lyric Theology}

In his essay, "Lyrical Theology," Tod Linafelt asserts that lyric poetry, over other modes of literary discourse, possesses the ability to reveal "genuinely

\footnotetext{
${ }^{19}$ As Thomas Linehan notes, "What may seem strange at first is that the moon imagery, so prominent on the opening page, disappears abruptly after the first paragraph, never to return. Clearly, O'Connor wants to establish immediately the notion of Christ as lover, and, in this parody of courtship with its extraordinary consummation at the end, nothing serves better than the conventional romantic associations of moonlight, here accompanying the noisy suit of the unbidden bull-god." Thomas M. Linehan, “Anagogical Realism in Flannery O'Connor," Renascence, 37/2 (1985): 91.
} 
new theological possibilities" ("Lyrical Theology," 303). ${ }^{20}$ The generic characterizations of lyric support and enable personal engagement with the poem, and according to Linafelt, lend itself to new theology. His claim intersects with my suggestion that a new understanding of God's erotic love blooms when "Greenleaf" and the Song of Songs are read together. If the Song as lyric poetry, indeed, by virtue of being lyric poetry, contains unique capabilities for revealing new theological discoveries, then that same text in dialogue with "Greenleaf" might further draw out and clarify those discoveries. In order to demonstrate what I mean, allow me to more closely retrace Linafelt's position.

Linafelt suggests that we consider lyric as a genre that lends unique insight to the practice of theology, separate from narrative theology: “... if the literary category (mode, or genre) of narrative holds possibilities for enlivening and enriching the theological task, might not the category of lyric hold such possibilities as well?" (“Lyrical Theology,” 292). In other words, lyric theology produces a richer and more textured understanding, of, in my view, the way Biblical texts and extra-canonical writings give themselves as sources for theological reflection. ${ }^{21}$

\footnotetext{
${ }^{20}$ Tod Linafelt, "Lyrical Theology," Toward a Theology of Eros: Transfiguring Passion at the Limits of Discipline, ed. Catherine Keller and Virginia Burrus (New York: Fordham University Press, 2006) 303.

${ }^{21}$ Linafelt himself does not seem to be totally clear about the object of application of this method, whether it is scripture, theological schools, or personal experience.
} 
For our purposes, I will focus on three primary features of lyric poetry: a focus on interiority, linguistic play, and intense emotional experiences. ${ }^{22}$ These features become the means through which lyric actually yields new theological possibilities. But before forging for new theological understanding generated by lyric, I will analyze a few verses from the Song in light of these three prominences of lyric poetry.

Through the defining features of lyric (inner life, linguistic play, and heightened emotional experience on the part of the reader), this genre comes to offer a unique advantage: it gives the reader an opportunity to radically identify with the characters in the text.

Lyric...tends to collapse the distance, but only for a moment, allowing the sympathy to be deeper and sometimes stranger as one takes on the voice of the fictive speaker of the poem and makes that speaker's passions or thoughts one's own. (ibid., 305)

Lyric's ability to "collapse the distance" arises from its presentation of inner life and linguistic play. Ideally, it results in the reader's affective experience. To take interiority first, it surfaces in the Song through speech, which the characters use to lay bare their inner world. Take as an example the opening verse of the third chapter: "Upon my bed at night / I sought him whom my soul loves; / I sought him, but found him not; / I called him, but he gave no answer." This passage begins to reveal the woman's inner world, accomplished through her voice.

${ }^{22}$ Lyric poetry more generally also displays "metrical-rhythmic structure," "brevity and density," "figurative content," "enthusiastic manner of composition," "subjectivity," and "reflexivity." Thomas Poiss, "Lyric Poetry," Brill's New Pauly: Encyclopaedia of the Ancient World: Volume Two, ed. M. Lanfester., et al, (Leiden: Brill, 2007) 361. 
We receive the plot directly from her, not the all-seeing, impersonal narrator. We get a glimpse of the degree to which these lovers yearn for one another. We start to sympathize for her-what's more, we start to empathize with her. In short, we identify with the characters presented in the text by coming into the inner circle of their hearts and minds as it manifests in their speech, without recourse to plot, narrative, or narrator.

In connection with and reinforcing inner life, linguistic play further aids the reader take on the experiences of the speaker by seduction through language. Rhythm, metaphor, and syntax attract and draw the reader more deeply into the text by lowering our skeptical sensibilities:

My beloved is like a gazelle / or a young stag. / Look, there he stands / behind our wall, / gazing in at the windows, / looking through the lattice. / My beloved speaks and says to me: / "Arise, my love, my fair one, / and come away; / for now the winter is past, / the rain is over and gone." (2.9-10)

Metaphor, though it comes into play immediately, does not clearly or definitively express a particular attribute of the beloved. Productive ambiguity functions in this metaphor that describes but does not reveal. Thus, ambiguity allows the reader to generate an image freely in the space opened up by the obscurity. This ambiguity grants the reader space to project one's own ideas of beauty or strength, to perform interactively what the image of a gazelle or stag might constitute. Further, on account of the structural aspect of ambiguity, the individual notion of how the image appears is impossible to definitively explain. The image results from singular experience, a moment indexing inner life. Likewise, 
the woman of the Song deploys the image of the gazelle from the resources and particularities of her own inner world. Thus her announcement "My beloved is like a gazelle" extends an invitation to the reader to repeat an expression from her own inner life or world. In this way, the space between the Song's signifying and what we receive as signification plays on the reader's interiority as it reinforces the interiority of lyric.

The lover's response also draws upon metaphor. But his speech is not merely metaphorical. When reading the Song, we must toe the line between what occurs in the outer world and what occurs in the inner world-and the event can be both at once. Recall, he has come to the window; but outside the wall, or inside her dream? This tension becomes a moment for linguistic play to bubble up in the cracks created by the space between imagination and reality. The lack of a determinate meaning asks the reader to participate more seriously in order to close the gap between actuality and fantasy, which in turn encourages greater emotional connection with the speaker. ${ }^{23}$ At its most successful, linguistic play is a lyrical poetic device that uniquely engages the reader by providing the necessary material to determine a meaning, thereby implicating oneself in the construction of the poem.

With lyric poetry outlined, I want to now put lyric theology into practice by taking a verse from the Song and implementing the defining features of lyric (inner life, linguistic play, emotional response).

23 "Lyrical Theology," 303. 
If we agree to define theology as discourse about and reflection on the ways of God, taking its lead from scripture, then lyric theology should be one that stimulates an affective response to the God we find in scripture. This emotional response should be accomplished through stimulating the reader's inner life, which encourages the reader to identify with the text. The connection should, in part, be made possible by linguistic play.

To put lyric theology into practice, and to test Linafelt's claim that lyric theology does disclose "genuinely new theological possibilities," I turn to the Song.

Set me as a seal upon your heart, / as a seal upon your arm; / for love is strong as death, / passion fierce as the grave. / Its flashes are flashes of fire, / a raging flame. / Many waters cannot quench love, / neither can floods drown it. (8.6-7)

Other verses, of course, offer possibilities for lyric theology. However, I chose this moment in the text for a few reasons. First, since lyric is most concerned with evoking emotion through emphasis on inner life and linguistic play, this particular moment in the text, concerned with both, is especially suitable. As for inner life, the speaker, indeterminate in this case, seems to demand out of inner plenitude that the beloved permanently bind himself to her. To take linguistic play, rhythm is the most operative play in verses six and seven, which accomplishes the content. That is, the rhythmic form of the verse repeats the rhythm of love between the two lovers. In this instance, there is a marriage between content and form, which in turn creates a fullness of text that spills out and onto the reader. Secondly, these verses represent the theological climax of the Song. As 
J. Cheryl Exum writes, “...everything [leading up this this point] converges upon and serves to illustrate the affirmation that love is strong as death" (Song of Songs: A Commentary, 3, emphasis mine). ${ }^{24}$ These verses are the nexus around which the rest of the book revolves, laying out and demonstrating what it here asserts. Indeed, they are the interpretive frame through which the rest of the text comes into focus. The lovers demonstrate how a love as strong as death manifests itself, making explicit what the lovers had been enacting up to this point. This insight, however, is not limited to the lovers alone. It becomes performative when the book itself echoes love's endurance: "The Song's resistance to closure, the way it circles back upon itself, is a defense against mortality" (Song of Songs: A Commentary, 245). The text performs a double function. Diegetically, love as strong as death resists the inevitable future by celebrating the present. The lovers are constantly bringing each other 'into the now,' through imagination or actually. Extra-diegetically, the text assumes the position it supports by attracting new interpretations all the time: the text will not die. ${ }^{25}$ As Exum writes, "without beginning and without end, the poem, like the love it celebrates, strives to be everlasting" (ibid., 245).

The lyrical theological approach to this text allows us to experientially undergo what is described there as a love as strong as death. That experience of

${ }^{24}$ Cheryl J. Exum, Song of Songs: A Commentary (Louisville: Presbyterian Publishing Corporation, 2005) 245.

${ }^{25}$ Diegesis, from the Greek for narration, is a term from film studies that refers to the events in the narrative as they unfold versus the way the film presents those events (the soundtrack, using long shots, and so forth). 
being a lover with a beloved, bound by a love this strong, raises questions about the bond between the two. What is it that allows for this great divider (death) to be powerless before this bond? In these verses six and seven, we hear for the first time an explicit characterization of what throughout the entire text was the operative force in principle: love. To quote again from Exum: "Now at last we hear expressed, in a few vivid images, what the poet has been showing us all along" (ibid., 245). Why does it appear, as explicitly named, at the end? Does it not point to an unseen reality governing this good that it sings? At the same time, it raises the question of the God who, it would seem, need not expressly be on the scene to be present. For what is the force of responsibility that I feel to and before this other? We sense the strength of love, the demands it makes, and the duty it creates. This is what the Hebrew Bible understands as the greatest of all commandments, and what the Christian New Testament calls the being of God. $^{26}$

Before we turn to "Greenleaf," we should not forget that the Song of Songs is an erotically charged text. Take for example, the second line of the poem: "Let him kiss me with the kisses of his mouth! / For your love is better than wine" (1.2). Or even more explicitly, "Awake, O North wind, / and come, / O South wind! Blow upon my garden / that its fragrance may be wafted abroad. Let my beloved come to his garden, / and eat its choicest fruits" (4.16). I argued above that the Song is concerned with the bond between the two lovers, and

${ }^{26}$ O'Connor makes a similar observation when she writes, "The Holy Spirit very rarely shows himself on the surface of anything" (Flannery O'Connor, The Habit of Being (New York: Farrar, Straus, and Giroux, 1979) 307. 
originates in God's own love. If that claim is granted, then it follows that God's love must include the valence of eros, because the erotic not only appears in this text, but the text also makes it its primary subject.

Keeping in mind the insights generated by a lyrical theological approach to the text, I now turn to "Greenleaf."

\section{Critical Reception of "Greenleaf"}

It will be helpful to take a brief account of the scholarship on "Greenleaf," in order to locate this essay in relation to other readings. "Greenleaf" like all of O'Connor's work, has been written on extensively, sometimes to surprising ends. For one, David Havird writes that it is another O'Connor story in which women ultimately lose "their pride to Christ:"

...it is the author's strategy in "Greenleaf"...to knock [this] proud female character down a notch-for Mrs. May that notch is death itselfby forcing upon [her], in a sexually humiliating and often violent way, the humbling knowledge that they are after all women. ("The Saving Rape: Flannery O'Connor and Patriarchal Religion") ${ }^{27}$

While Havird notes the erotic subtext in "Greenleaf," he misinterprets how it functions. Concerning issues of sexuality more generally, the moment a bull enters the scene, classical myth must become part of the conversation. ${ }^{28}$ More relevant to my project, a number of scholars have noticed intertextuality between our primary texts. Havird himself acknowledged that certain parts of the story

\footnotetext{
${ }^{27}$ David Havird, “The Saving Rape: Flannery O'Connor and Patriarchal Religion," Mississippi Quarterly 47/1 (1993): 15.

${ }^{28}$ For a good example, see: John C. Shields, "Flannery O'Connor's 'Greenleaf' and the Myth of Europa the Bull," Studies in Short Fiction 18/4, (1981): 421-431.
} 
are reminiscent of the Song. In reference to the bull's behavior towards Mrs. May, he writes, that “... [it] brings to mind the second Song of Solomon [2.89]."29

Others, such Frederick Asals, assert that O'Connor borrows from the Song's eroticism to portray Christ's profound love for the church. ${ }^{30}$ While these writers offer a helpful starting place, the character of God's love as it appears in "Greenleaf" goes further than they present it. In the case of Asals, he says of "Greenleaf" that it "seems to harbor no longing, however suppressed, for the divine." ${ }^{31}$ I do not want to take this direction. On the contrary, I maintain that “Greenleaf” actually does offer a vision of reciprocal Divine union. Louise Westling, in line with Asals, remarks that the "vulnerable womanhood of the farmowning mothers and the predatory malice of their male adversaries sets the stories apart from traditional use of the lyric eroticism of the Song of Songs." ${ }^{\text {32 But }}$ it is precisely the erotic content and the lyric form, respectively, that these authors overlook. ${ }^{33}$

29 "The Saving Rape," 17. Havird further writes that "Greenleaf" exhibits other parallels with the Song, namely, the window and dream scenes that we considered above.

${ }^{30}$ Frederick Asals, Flannery O'Connor: The Imagination of Extremity (Athens: University of Georgia Press, 2007) 223.

${ }^{31}$ Flannery O'Connor: The Imagination of Extremity, 223.

${ }^{32}$ Sacred Groves and Ravaged Gardens, 159.

${ }^{33}$ O'Connor herself wrote very little about "Greenleaf." She says that it is a good story (The Habit of Being, 146), and that she was pleased to be writing it: "I am very happy right now writing a story in which I plan for the heroine, aged 63, to be gored by a bull...it is going to take some doing to do it and it may be the risk that is making me happy (The Habit of Being, 129). 
The conversation between the texts that I suggest in this project displays its strength in light of these interpretations. As readers of the Song, we have been prepared by its lyric form, which emphasizes inner life and affective engagement with the text. In addition, having explored Gadamer's theory of art, we are ready to allow the texts to comment on one another. And it is the conversation between texts, mediated by the reader, that illuminates the question of God's erotic love.

Without overturning the interpretations offered by Havird, Shields, Asals, and Westling, I aim to give an alternate reading, developed out of Gadamer's model of play. I argued above that repetition is not a mere imitation, but presents possibilities for newness within a set of established boundaries. "Greenleaf" is no mere imitation of the Song. Rather, the story takes up the same underlying question as the Song in order to give further expression to God's erotic love. It would be reductive and unconvincing to treat "Greenleaf" as principally recasting the Song in new light. Instead, the story, enriched by our lyrical theological hermeneutics of play, becomes another way Divine erotic love can be reckoned with.

\section{A Close Reading of "Greenleaf"}

The first conversation the reader hears between Mrs. May and Mr. Greenleaf centers on her demand that the bull be "penned up" immediately. In this same conversation, Mrs. May asks who the bull belongs to, to which Mr. 
Greenleaf answers simply that "he must be somebody's bull." Mrs. May, exasperated, replies, "Yes, he must!" and mocks this same exchange later to her sons (“Greenleaf," 504). This interaction parodies Song 2.16a, "My lover belongs to me and I to him," a repeated exclamation throughout the Song. That is, the bull belongs to none other than Mrs. May, and she to him. This question of possession invokes the erotic, because the female lover of the Song most certainly means to claim that component of love in her declaration.

\section{Divine Erotic Love}

There can hardly be any doubt that "Greenleaf" does contain underlying eroticism throughout. ${ }^{34}$ More specifically, the story blends the erotic with the speed of grace at the end of the story. Within the course of the narrative, Mrs. Greenleaf's prayer healing contains sensual overtones. When Mrs. May witnesses Mrs. Greenleaf's ritualistic practice, it brings to her mind subjects belonging to the bedroom. Further, Mrs. Greenleaf's posture is described as "obscene" (“Greenleaf," 506-507). O'Connor herself connects Mrs. Greenleaf and the bull (The Habit of Being, 148). This ritual, where Mrs. Greenleaf earnestly prays for grace to heal, points to this connection. That is, we discern the link between the bull and Mrs. Greenleaf more clearly when we consider Mrs. May's premonition

\footnotetext{
${ }^{34}$ Michael Raiger writes that the erotic is "a theme that at all times lies just below the surface of the narrative." Michael Raiger, "The Grotesque and the Sublime in the Short Stories or Flannery O Connor," Seeing into the Life of Things: Essays on Literature and Religious Experience: Volume One, ed. J. L. Mahoney, (New York: Fordham University Press, 1998) 252.
} 
upon the sight of Mrs. Greenleaf, namely, that: “...some violent unleashed force had broken out of the ground and was charging toward her" ("Greenleaf," 506). This scene does more than just foreshadow the bull goring Mrs. May; it establishes a connection between Mrs. Greenleaf 'praying for grace to intervene,' and Mrs. May's being penetrated by the force of grace. As a reflection of that coming encounter, it is fitting that Mrs. Greenleaf's posture be vaguely erotic, and that she would cry out, "Oh Jesus, stab me in the heart!" ("Greenleaf," 506), because this cry is actualized in Mrs. May.

O'Connor was undoubtedly familiar with traditional Christian interpretation of the Song, which treats it allegorically and takes the groom to be Christ. Moving forward, I want to take up the theme of love that does not immediately oppose New Testament agape to Greek eros. Both texts overcome the idea of an impersonal love of God. Accordingly, eros will refer to passion, desire, and even the feeling associated with sexual affection. ${ }^{35}$ Ralph Wood's essay, "Flannery O'Connor, Benedict XVI, and Divine Eros" will be a useful source for expanding on this issue. ${ }^{36}$

\footnotetext{
${ }^{35}$ There are, of course, other ways God's love can be understood: “...loving God usually stands in parallel with fearing God, serving God, keeping God's commandments, and walking in God's ways ([cf.,] Deut 10:12; 11:1, 13, 22; 13:4f.; 19:9; 30:6, 16, 20; Josh 22:5; 23:11; also $1 \mathrm{Kgs} \mathrm{3:3)."} \mathrm{Hans-Christoph} \mathrm{Schmitt,} \mathrm{Michèle} \mathrm{Morgen,} \mathrm{Kon-}$ rad Stock, Friedrich Avemarie, Gerold Necker, and Bernd Radtke, "Love of/for God," Religion Past and Present (Leiden: Brill, 2011) 247-256. While these are all valid, our primary interest of Divine eros indicates a different kind of loving.

${ }^{36}$ Ralph Wood, "Flannery O'Connor, Benedict XVI, and Divine Eros," Christianity and Literature 60/1 (2010).
} 
In order to bring to light how Divine eros features in "Greenleaf," we must take recourse to O'Connor's theological persuasions, which Wood convincingly elucidates. Wood's first assertion of import for us is O'Connor's conviction that the Modern world was guilty of Manichaean dualistic tendencies. Wood further writes that the action of grace as it functions in O'Connor's work can be better understood in relation to la nouvelle théologie, and more specifically, Pope Benedict XVI. Although O'Connor died shortly after this school of theology became prominent, Wood's primary claim in his essay is that her work is "thoroughly congruent with the theology of Benedict XVI." ${ }^{37}$ As a point of connection between O’Connor and Benedict, Wood cites Charles Péguy, “...she hailed the work of the French poet and mystic Charles Péguy, a crucial influence on [la nouvelle théologie]...she stressed Péguy's importance for the twentiethcentury Catholic Revival, especially his helping overcome the lamentable bifurcation of nature and grace" ("Divine Eros," 46). O'Connor's work similarly bears the mark of a burgeoning gap between nature and grace, where the "action of grace" intervenes in a "territory largely held by the devil.",38

Seeing resonances of Benedict's work to overcome "destructive dualisms," Wood points to the polarization of agape and eros.

Of Benedict's many writings, his [encyclical]...titled God is Love has the fullest relevance to Flannery O'Connor's work. There the pope argues that the standard contrast between eros and agape is based on a neo-scholastic rendering of the nature-grace relation-the mistaken notion, namely, that only when worldly love exhausts or bankrupts itself

\footnotetext{
37 "Divine Eros," 46.

${ }^{38}$ Flannery O'Connor, Mystery and Manners (New York: Farrar, Straus, and Giroux, 1970) 118.
} 
can divine love then complete and perfect it. [Benedict XVI] confesses that the [Catholic] Church has sometimes been guilty of this false divide, thereby opposing our bodily life as if it were something deleterious if not irrelevant to our spiritual life. (ibid., 42)

O'Connor believed that the modern world found itself in an ever-increasing state of radical divides. One such example, eros and agape, rather than essentially being split, are actually parts of a whole: "true eros finds its fulfillment rather than its frustration in agape" (ibid., 42). Spirit and matter, body and soul are meant to be in concord. Erotic expression does not represent the antithesis of spirituality. Indeed, it can actually serve as "an authentic sign of the human hunger for and expression of the Holy" (ibid., 42).

It follows that the representation of God as lover and humanity as beloved assumes a theological significance. To quote again from Wood:

The most arresting aspect of Benedict XVI's encyclical is... his contention that God's love must be interpreted... as the divine eros for humanity. Against the conventional reading of eros and agape set against each other-the one worldly and the other Christian-the pope insists that the two loves are not only meant to be properly integrated within human life but that they are already thus integrated in the divine life. God's own love is erotic no less than agapeistic. (ibid., 44)

We see the fusion of eros and agape in "Greenleaf." Both of these aspects of Divine love come together to yield a moment of grace. Thus, "Greenleaf" offers a narrative frame for the agapeistic and erotic love of God, and results in the piercing eruption of grace into Mrs. May's life. That is, in "Greenleaf," the bull behaves erotically in response to his agapeistic love for his beloved. Needless to 
say, we see Divine love, both eros and agape, permeating the Song of Songs as well. $^{39}$

While the erotic nature of the Song is prominent, finding it in "Greenleaf," it should be admitted, requires greater investigation. The Biblical text becomes a resource for locating the erotic in the story. As a spectator, the reader notices textual echoes, but only as a player is the reader enabled to name God's love in each text.

Before considering the culminating image of the bull as Christ figure, I now consider the role and significance of the Greenleaf family.

\section{Symbolism Relating to the Mays and the Greenleafs}

The Greenleaf and May names are meaningful, not only for their connotation of spring, but also for their contribution to interpreting the story. One scholar, locating the origins of the Greenleaf name in the Bible, quotes Proverbs 11.28, "He who trusts in his riches shall fall, but like green leaves the just shall flourish." As Perry goes on to write, the Greenleafs do spring up, and "...outnumber Mays, after all, by a tally of seventeen to three" ("Straining the Soup Necessarily Thinner," 57). If we grant Perry's assertion that Proverbs 11.28 is the root of the Greenleaf name, then this has lasting implications for

\footnotetext{
${ }^{39}$ Benedict wrote about this Biblical text, which he saw as evidencing the simultaneous presence of both aspects of God's love: "Thus the Song of Songs became... a source of mystical knowledge and experience, an expression of the essence of biblical faith: that man can indeed enter into union with God... it is a unity which creates love, a unity in which both God and man remain themselves and yet become fully one" (ibid., 44).
} 
understanding Mrs. May. Her chief concern is the farm and its success, and everything else filters through this primary interest. When she speaks to and about her sons, she cares more about who they marry, and by implication, into whose hands the farm will ultimately fall after her death, than she does the boys themselves. In fact, the only two subjects Mrs. May discusses at all are the farm and the bull.

The farm is a source of pride for Mrs. May, "Her city friends said that she was the most remarkable woman they knew, to go, practically penniless and with no experience, out to a rundown farm and make a success of it" ("Greenleaf," 511). Mrs. May stands guilty of two related things. In terms of the verse quoted from Proverbs, she has placed her faith in economic gain. The second is pride, "[that] terrible radical human pride that causes death" (The Habit of Being, 307). Contrasted with Mrs. May's faults, the Greenleafs "thank Gawd for ever-thang," ("Greenleaf," 514), and, correspondingly, they "spring up as green leaves." The Greenleafs and the Mays each depict the two halves of Proverbs 11.28 .

Yet we can say more about this stark contrast between the Mays and the Greenleafs. The verse specifies that the "just" shall spring up. In "Greenleaf," the "just" bring Mrs. May's sins into view by juxtaposition. Mrs. May, after the bull has escaped, seeks out O.T. and E.T Greenleaf at their house to tell them to retrieve him immediately. She does not find the twins, however, but their children. "Presently the door opened and several children appeared in it and stood looking at her...'Can't one of you children come here?' She called. After a mi- 
nute they all began to move forward, slowly" ("Greenleaf," 513). After attempting to connect with the children, only for it to repeatedly fall flat, Mrs. May "[feels] as if she were on trial for her life, facing a jury of Greenleafs" ("Greenleaf," 514). And indeed, her feeling is correct. Mrs. May's life does hang in the balance. The Greenleafs, who do not fall prey to the lure of money or pride, do become the standard against which she is judged. Their thankfulness, by contrast, condemns her prideful attitude of heart.

Mrs. May's trip to the Greenleaf property, in addition to serving her pride by asserting command over the Greenleafs, also satisfies her curiosity. Having never visited their home, she wants to discover how the Greenleafs live and compare it with her own life. To her chagrin, she finds that they prosper. ${ }^{40}$ While she investigates the house, she discovers the twins' new milking parlor. Mrs. May, who does not own the latest state-of-the-art equipment, seethes with resentment. She inspects the parlor to check if they "[keep] it clean." She finds that not only is it spotless, it is also blindingly bright. "She opened the milking room door and stuck her head in and for the first second she felt as if she were going to lose her breath. The spotless white concrete room was filled with sunlight...she had to squint to be able to look at all" ("Greenleaf," 515). The symbolism of the sun relates not only to Mrs. May here, but also the Greenleafs later. We will return to this below. For now I want to transition from the May and Greenleaf family, to Mr. Greenleaf specifically.

${ }^{40}$ In Mrs. May's mind, they have her to thank for their success “.... if the Greenleaf boys had risen in the world it was because she had given their father employment when no one else would have him" (“Greenleaf," 502). 
Mr. Greenleaf "walk[s] on the perimeter of some invisible circle ("Greenleaf," 503). Of his appearance, "The upper part of his face sloped gradually into the lower which was long and narrow, shaped like a rough chalice. $\mathrm{He}$ had deep-set fox-colored eyes shadowed under a grey felt hat that he wore slanted forward following the line of his nose" ("Greenleaf," 503). The description of Mr. Greenleaf's face as a "rough chalice" evokes the "Eucharistic Prayer" of the Catholic liturgy and its "chalice of blessing," itself an echo of St. Paul's first letter to the Corinthians (10.16): "The cup of blessing that we bless, is it not the sharing of the blood of Christ?" Mr. Greenleaf appears not only to be the patriarch of a righteous family, but also a priestly figure. Mrs. Greenleaf, for her part, gathers up all of the suffering of the world she can (by way of newspaper clippings) and makes that suffering her daily prayer (see "Greenleaf," 505-506). Together, they have conceived a family that "live[s] like the lilies of the field" (“Greenleaf," 509). Indeed a family "as a lily among brambles" (Song 2.2).

Mrs. May's repeated insistence that Mr. Greenleaf slaughter the bull takes on a grotesque light in view of Mr. Greenleaf's priestly characterization and the bull's Christ-like connotations. In fact, the basis for the claim that "Greenleaf" picks up and demonstrates God's erotic love for the church is rooted in the bull's representation as a Christ-like figure. First, I return to the symbolic relevance of the sun. ${ }^{41}$ Then, because the resonances of the bull as a Christ

${ }^{41}$ For a useful essay about the sun in O'Connor's work generally, see: Stuart L. Burns, “Torn by the Lord's Eye: Flannery O'Connor's Use of Sun Imagery” Twentieth Century Literature 13/3 (1967): 161. 
figure reach prominence at the end of the story, I group these together and examine them simultaneously.

\section{The Sun}

In support of my treatment of the sun as it appears in "Greenleaf," I will draw upon Peter Candler's essay, “The Anagogical Imagination of Flannery O'Connor," which requires first making a concise account of anagogical vision. $^{42}$

The sun is related to vision in much of O'Connor's work. Candler argues that ordinary vision becomes anagogical after grace erupts into a character's life. As he writes, "To see the world rightly is to see it anagogically, to see it in terms of 'the Divine life and our participation in it,' [Quoting Mystery and Manners]" (“Anagogical Imagination," 13). O'Connor writes that "anagogical vision...is the kind of vision that is able to see different levels of reality in one image or situation" (Mystery and Manners, 72). This principle permeates and animates "Greenleaf." It is a vision that can result in distortion, but a kind that mirrors the distortion of distance, like a far-off tower appearing small. What O'Connor calls the "[realist of distances]...does not hesitate to distort appearances in order to show a hidden truth" (Mystery and Manners, 179). Gadamer,

${ }^{42}$ The four levels of meaning according to traditional Christian exegesis are the literal, allegorical, moral, and anagogical. One of the most important figures of la nouvelle théologie, Henri de Lubac considers this issue at length. See: Henri de Lubac, Medieval Exegesis: The Four Senses of Scripture: Volume Two (Grand Rapids: Eerdmans, 1999). 
when he speaks of an artist "pointing to something...has to exaggerate, whether he likes it or not" (Truth and Method, 119), hits upon the same phenomenon. "Greenleaf," in depicting a bull as a lover, distorts to the point of risking a break. But keeping in mind the hermeneutics of play and lyrical theology, the distortion present in "Greenleaf" actually helps to reveal in God's love a "hidden truth." Because of the radical nature of that concept, "Greenleaf" responds in kind, with its own radicalness. But in order to appreciate this move fully, we must return to the image of the sun.

O’Connor believed that modernity suffered from relentless dualisms, which resulted in the separation of nature and grace, matter and spirit, agape and eros, and so on (ibid., 18). We first learned of this split from Wood's essay “Flannery O’Connor, Benedict XVI, and Divine Eros." Candler, for his part, argues that O'Connor's common metaphor for the reunification of these dualisms is the sun, or otherwise, light: "Her metaphor for this [union of the visible and the invisible] is the terrestrial source of light itself, the sun, which not only illumines but also burns" (“The Anagogical Vision of Flannery O'Connor,” 22). The reunification of these dichotomies ushers in anagogical vision. O'Connor works to reintegrate nature and grace by weaving light into the fabric of the encounter with grace, thus hinting at the restoration of vision through grace.

Light becomes an extension of grace that we can track, so to speak, in the images of the sun. In "Greenleaf," we have a sense of the sun haunting us throughout the story, and its presence is frequently noted. When the sun is described with respect to the Greenleafs, it indicates a source of usefulness. The 
sun shines directly onto their house, ("Greenleaf," 513), the sun drenches the milking parlor (“Greenleaf," 515), and Mr. Greenleaf suns milk cans when Mrs. May demand that he shoot the bull ("Greenleaf," 519). On the other hand, the presence of sun in regard to Mrs. May frequently reveals either her apprehension, or her coming encounter with grace. When she leaves the Greenleafs' milking parlor, the sun hangs directly over her head, "like a silver bullet ready to drop into her brain" (ibid., 519). Mrs. May watches the sun slowly disappear behind Mr. Greenleaf as she informs him that she wants the bull dead (ibid., 518). She dreams on the eve of her death that the sun transforms into a bullet that races towards her (ibid., 519). And finally, as she waits for Mr. Greenleaf to shoot the bull, she feels the presence of the sun overhead, just moments before the bull does indeed race towards her (ibid., 522). The meaning of these appearances of the sun, in relation to Mrs. May, orbit around the moment of her death. They indicate her coming encounter with grace, and situate it within the natural world. When the bull strikes, as repeatedly hinted by the sun, the reunification of grace and nature is signified by the restoration of Mrs. May's vision.

Having taken stock of the sun imagery in "Greenleaf," we are in a better position to turn finally to the bull, and to Christ. In the case of "Greenleaf," by calling the bull a Christ-like figure, it is to be understood that the first- the bull - is a type of the second-Christ ("The Anagogical Vision of Flannery O'Connor," 24). This means that the bull represents "Christ's earthly nature," (“Torn by the Lord's Eye," 161). 


\section{The Bull and Christ}

The first and most evocative association of the bull and Christ comes on the second page of the story. We know that the story begins with the bull coming to Mrs. May's window and chewing the hedge, an act that causes the hedge to form a wreath around his horns. Once Mrs. May looks out her window, he "lower[s] his head [to shake] it and the wreath $\operatorname{slip}[\mathrm{s}]$ down to the base of his horns where it look[s] like a menacing prickly crown," ("Greenleaf," 502) much like Christ's crown of thorns (which all four gospels describe in the passion narrative). But why "Greenleaf" includes an image saturated with the suffering of Christ during his crucifixion is not readily apparent.

Mrs. May is the first and only of O'Connor's characters to lose her life to gain grace, enacting literally and physically Jesus's promise that "those who lose their life for my sake will find it" (Matthew 16.25b). ${ }^{43}$ She is also the first and only character who receives grace in the form of an "emissary of God" penetrating her body in half wound and half embrace. ${ }^{44}$ Any artful depiction of Christ in this way risks falling into blasphemy. O'Connor herself reflected on

\footnotetext{
${ }^{43}$ Even counting the grandmother in "A Good Man is Hard to Find." Her encounter with grace is just before her death, they do not occur in the very same moment, as in "Greenleaf."

44 Jane Marston, "Epistemology and the Solipsistic Consciousness in Flannery O'Connor's 'Greenleaf," Studies in Short Fiction, 21/4 (1984): 379. Concerning grace, the argument could be made that every time a character finds themselves on the receiving end of grace, it is through an "emissary of God." However, the deliverance of grace in "Greenleaf" is categorically different. No other characters experience the force of grace in their bodies. Even, again, the grandmother in "A Good Man is Hard to Find," who is shot to death, faces a mediating object (the gun), which is not the body of Christ.
} 
that risk: "My preoccupation is how I am going to get this bull's horns into this woman's ribs" (The Habit of Being, 149). The technical distance between Mrs. May's rib and the bull's horn begins to be bridged by the passion of Christ. That is, the bull, who represents Christ, fatally pierces Mrs. May because of his love for her. The point is not that a sacrifice must be rendered, but that a "love as strong as death" hesitates before nothing.

This brings us to the conclusion of "Greenleaf." Mr. Greenleaf does not want to slaughter the bull, and Mrs. May takes extreme pleasure in pushing the matter against his will: "He'd like to shoot me instead of the bull, she thought, and turned her face away so that he could not see her smile" ("Greenleaf," 520). Mrs. May and Mr. Greenleaf track the bull through a series of three pastures. While in the second pasture, Mrs. May "[drives] around the rim of the pasture until she spot[s] the bull, almost in the center of it" ("Greenleaf," 521). Upon finding him, Mrs. May says to Mr. Greenleaf that the bull is waiting for him. While she correctly notes that the bull waits, she is mistaken about for whom he does so. The "patient god come down to woo her" comes full circle. Mr. Greenleaf, in order to get the bull's attention throws a rock at him, which in turn makes the bull "gallop until he disappear[s] over the rim of the hill" ("Greenleaf," 521). Mr. Greenleaf follows him into the tree line, leaving Mrs. May alone in the field.

While Mrs. May waits for Mr. Greenleaf and the bull to reappear, she drives "to the center of the pasture" (ibid., 521). Now Mrs. May, switching positions with the bull, is the one left waiting. She sits on the hood of the car, and 
the sun, red hot, beats down on her overhead (ibid., 522). There is a piercing blindness to its intensity, forcing her eyes closed and lulling her to sleep. She flits through a series of thoughts, all accurate, and all self-aggrandizing.

She decided that she had every right to be tired...before any kind of judgment seat, she would be able to say: I've worked, and I have not wallowed. At this very instant while she was recalling a lifetime of work...Mrs. Greenleaf was probably flat on the ground, asleep over her holeful of clippings... 'I'm afraid your wife has let religion warp her,' she once said tactfully to Mr. Greenleaf.” (“Greenleaf," 522)

Wallowing, however, precisely characterizes her behavior throughout the story. As for religion, she alone has become warped by it, condemning Mrs. Greenleaf's genuine expression of faith and prayer for grace. She begins to wonder about Mr. Greenleaf, imaging that perhaps the bull has gored $\mathrm{him} .{ }^{45}$ Increasingly irritated and impatient with the fact that "I have sought him, but did not find him" (Song 5.6b), Mrs. May honks the horn three times and her lover finally responds to her call.

In a few minutes something emerged from the tree line, a black heavy shadow that tossed its head several times and then bounded forward. After a second she saw it was the bull. He was crossing the pasture toward her at a slow gallop, a gay almost rocking gait as if he were overjoyed to find her again. ("Greenleaf," 523)

Mrs. May almost asks herself, "What is that coming up from the wilderness, / like a column of smoke" (Song 3.6a), "leaping upon the mountains / bounding over the hills" (Song 2.8b). The bull's joyful rocking expresses his enthrallment to find his beloved, this time to consummate their love. And Mrs. May displays no sign of fear. Like the woman of the Song's "Look!" so Mrs. May calls out to Mr. Greenleaf that the bull has arrived.

${ }^{45} \mathrm{O}$ 'Connor is rather heavy handed with the irony in this moment. 
She looked back and saw that the bull, his head lowered, was racing toward her. She remained perfectly still, not in fright, but in a freezing unbelief. She stared at the violent black streak bounding toward her as if she had no sense of distance, as if she could not decide at once what his intention was, and the bull buried his head in her lap, like a wild tormented lover, before her expression changed. One of his horns sank until it pierced her heart and the other curved around her side and held her in an unbreakable grip. She continued to stare straight ahead but the entire scene in front of her had changed-the tree line was a dark wound in a world that was nothing but sky - and she had the look of a person whose sight has suddenly been restored but who finds the light unbearable. ("Greenleaf," 523)

This passage, so rich and complex, harbors the crux of the connection between our source texts.

We as readers find no trace of Mrs. May experiencing anger or fear. She seems unable to decide what she feels. Mrs. May thinks of the other, the bull, and, finally, not of herself. But she cannot decide what his intention is. Like the woman of the Song's exclamation, "his intention toward me [is] love" (Song 2.4b), the bull's intention toward Mrs. May, similarly, appears to be love.

Almost as a response to her query about intention, the bull answers bylovingly_-burying "his head in [Mrs. May's] lap, like a wild tormented lover." The patient suitor from before is gone, and a lover tormented by desire takes his place. One horn pierces her heart, the wound of love, and the other embraces her in an unbreakable grip, as though "His left hand [were] under my head / and his right hand embraces me" (Song 2.6, 8.3). Mrs. May's and the bull's union in death generates the encounter with grace. Her expression does not change until they have been physically united: grace and death bleed into the same moment. Bringing the consummating scene to a close, 
[Mrs. May] saw [Mr. Greenleaf] approaching on the outside of some invisible circle... He shot the bull four times through the eye. She did not hear the shots but felt the quake in the huge body as it sank, pulling her forward on its head, so that she seemed, when Mr. Greenleaf reached her, to be bent over whispering some last discovery into the animal's ear. ("Greenleaf," 524)

Mrs. May feels her lover tremble in her own body, and lowering his head once more, draws Mrs. May even closer. The imagery, "almost entirely sexual, is deeply under scored with spiritual meaning." 46 She shares with her lover something that remains mysterious in detail to the reader: perhaps gratitude, perhaps grace. Does she receive in this moment the realization of Jesus's promise to those who lose their life? Does she understand what a love as strong as death is like?

\section{Synthesis of "Greenleaf" and the Song of Songs}

Intimations of the unique insight "Greenleaf" and the Song lend to Divine eroticism have already begun to surface. But they must be more carefully worked out in this concrescence of the story and Biblical book.

The first consideration is an insight we arrived at through lyric theology. The defining features of lyric asks the reader to inhabit the poem. But more than simply imagining the world of the poem and casting two imaginary actors, lyric demands that reader go a step further: to "speak the words of the poem as

\footnotetext{
${ }^{46}$ Ruth M. Vande Kieft, "Judgment in the Fiction of Flannery O'Connor," The Sewanee Review, 76/2 (1968): 350.
} 
though we were their first utterers" ("Toward a Theology of Eros," 300). ${ }^{47}$ Identification of the kind that lyric requires is more drastic than a sympathetic imagination. Participating in this way means to take the place of the speaker presented on the page. By way of this potentially radical involvement, I came to question what the lovers share between each other. Love is the obvious answer, but the depth of my involvement reaches for the motivation for that bond, the well from which it originally sprung. For myself, I came to see that God's own love is implicated in this relationship, perhaps its source. We find no need to draw upon allegory to symbolically include God in the Song.

The lyrical poetry of the Song brings God forth in an erotic setting. But what of a more theologically developed account of Divine eroticism? Ralph Wood, in his essay on Flannery O'Connor and Divine eros, helped us to substantiate the theological legitimacy of Divine eros and its role in "Greenleaf." Wood's essay gives ground to see in "Greenleaf" that the fragmented pieces of God's love, eros and agape, disastrously separated, are actually parts of a whole. The bull's erotic pursuit is, at once, a pursuit of God seeking Mrs. May's redemption, and therefore agapic. It is a love that can be erotic, even when its source is agapic.

"Greenleaf," in putting forth an evocative meditation on the pursuit of grace in the modern world, rips open space to contemplate God's erotic love. The texts become dialogic by virtue of engaging the same topic. The reader, as

\footnotetext{
${ }^{47}$ Helen Vendler, Poems, Poets, Poetry: An Introduction and Anthology: Second Edition (Boston: St. Martin's Press, 2002) 183. Cited in "Toward a Theology of Eros."
} 
player, can pursue these moments of connection and allow the texts to comment on one another. When these two texts are taken together, they offer a multifaceted entry into the topic of God's erotic love. Specifically, the topic of a love as strong as death. Yet we can say more about this principle, "as strong as death." The exploration of the Song in the mode of lyric theology, drew out the lover's performance of a love as strong as death, and exposed the reader to its ardor. Coming to "Greenleaf" with the same ardor, we do not simply see a woman gored to death. We see a love as strong as death played out.

It would seem, however, that "Greenleaf" has ambition in addition to dramatically enacting the Song. We are, I suggest, led from our insights from lyric theology, into conversation with O'Connor's idea of anagogical vision. Grace restores vision, and the speed of grace is erotically charged. Seeing anagogically, then, offers visibility to all forms of God's love. Even if "to see anagogically is to perceive in the world a plenitude that is nevertheless not properly an object of sight" (“Anagogical Vision," 22), nonetheless, in an eruption of grace, we are permitted to catch a glimpse of it.

My method for uncovering Divine eros in the source texts was to become a player. Freely moving back and forth between "Greenleaf" and the Song of Songs allowed me to display the underlying question that each text takes up. Gadamer's construction of play has provided a useful model to frame the texts, and to describe the role of the reader in both demonstrating and exploring the moments that echo one another. I have argued that each text grapples with Divine eros. "Greenleaf," through its own presentation of themes, plot, dialogue, 
and characterization culminates in death, prompted by love. "Greenleaf" and the Song together perform "a love as strong as death." However, "Greenleaf" becomes the Song's inverse, and in this way, completes it. Indeed, Mrs. May can be seen as the inverse of the lover in the Song, who in a glimpse of grace experiences the Divine love for what it is, erotic and agapic. The texts taken together depict love springing from a source that draws no distinction between eros and agape.

To end in O'Connor's voice, 'God's love for us is so great that He does not wait until we are purified to such a great extent before he allows us to receive him" (The Habit of Being, 387). 


\section{Works Cited}

Asals, Frederick, Flannery O'Connor: The Imagination of Extremity (Athens: University of Georgia Press, 1982).

Burns, Stuart L., “Torn by the Lord's Eye: Flannery O’Connor's Use of Sun Imagery" Twentieth Century Literature 13/3 (1967): 154-166.

Candler Jr., Peter M. “The Anagogical Imagination of Flannery O’Connor” Christianity \& Literature 60/1 (2010): 11-33.

Exum, Cheryl J., Song of Songs: A Commentary (Louisville: Presbyterian Publishing Corporation, 2005).

Gadamer, Hans-Georg, Truth and Method (New York: Continuum, 2004 [1960]).

Havird, David, “The Saving Rape: Flannery O’Connor and Patriarchal Religion” Mississippi Quarterly 47/1 (1993): 15-26.

Kieft, Ruth M. Vande, “Judgment in the Fiction of Flannery O'Connor" The Sewanee Review 76/2, (1968): 337-356. 
Kinney, Arthur. F., “O’Connor, Flannery” in S. Serafin, and A. Bendixen (eds.), Continuum Encyclopedia of American Literature (Continuum, 2005): 838-841.

Linafelt, Tod "Lyrical Theology," Toward a Theology of Eros: Transfiguring Passion at the Limits of Discipline, ed. Catherine Keller and Virginia Burrus (New York: Fordham University Press, 2006): 291-303.

Linehan, Thomas M., “Anagogical Realism in Flannery O’Connor” Renascence 37/2 (1985): 80-95.

Lubac, Henri de, Medieval Exegesis: The Four Senses of Scripture: Volume Two, (Grand Rapids: W.B. Eerdmans, 1999).

Marston, Jane, "Epistemology and the Solipsistic Consciousness in Flannery O’Connor's 'Greenleaf'” Studies in Short Fiction 21/4 (1984): 75-82.

O'Connor, Flannery, and Sally Fitzgerald and Robert Fitzgerald (eds.), Mystery and Manners (New York: Farrar, Straus, and Giroux, 1970).

The Habit of Being (New York: Farrar, Straus, and Giroux,1979).

Collected Works (New York: The Library of America, 1988). 
— A Prayer Journal (New York: Farrar, Straus, Giroux, 2013).

Poiss, Thomas, "Lyric Poetry" in Landfester, M., et al. (eds.), Brill's New Pauly: Encyclopaedia of the Ancient World, Antiquity: Volume Two: (Lei den: Brill, 2007).

Perry, Keith, “Straining the Soup Necessarily Thinner: Flannery O'Connor's 'Greenleaf' and Proverbs 11:28” English Language Notes 42/2 (2004): 56-59.

Raiger, Michael, "The Grotesque and the Sublime in the Short Stories of Flannery O Connor" in J. L. Mahoney, (ed.) Seeing into the Life of Things: Essays on Literature and Religious Experience: Volume One: (New York: Fordham University Press, 1998): 242-270.

Schmitt, Hans-Christoph, Michèle Morgen, Konrad Stock, Friedrich Avemarie, Gerold Necker, and Bernd Radtke, "Love of/for God," in Religion Past and Present (Leiden: Brill, 2011).

Shields, John C., “Flannery O'Connor's 'Greenleaf' and the Myth of Europa and the Bull" Studies in Short Fiction, 18/4 (1981): 421-431. 
Soulen, Richard N., "The Wașfs of the Song of Songs and Hermeneutic" in A. Brenner (ed.), A Feminist Companion to the Song of Songs (Sheffield Academic Press, 1993).

Vendler, Helen, Poems, Poets, Poetry: An Introduction and Anthology, 2nd ed. (Boston: Bedford/St. Martin's Press, 2002).

Watson, Jay. "Flannery O'Connor" in Bercovitch, S., and C. Patell (eds.) The Cambridge History of American Literature, vol. VII (1940-1990) (Cambridge: Cambridge University Press, 1994): 347-355.

Westling, Louise, Sacred Groves and Ravaged Gardens: The Fiction of Eudora Welty, Carson McCullers, and Flannery O'Connor (Athens: University of Georgia Press, 1985).

Wood, Ralph, “Flannery O’Connor, Benedict XVI, and Divine Eros.” Christianity and Literature 60/1 (2010): 35-64. 